Mariusz E. Sokołowicz*

ROZDZIA $ヒ$ I

\title{
Wpływ korporacji transnarodowych na wzmacnianie kapitału ludzkiego w regionie. Studium przypadku Łódzkiego Obszaru Metropolitalnego
}

\section{Kapitał ludzki i jego związek z procesami rozwoju regionalnego}

Znaczenie kapitału ludzkiego w rozwoju gospodarczym opisuje się w naukach ekonomicznych od końca lat 50. XX wieku. Choć fakt, że człowiek i jego umiejętności powinny być postrzegane jako forma kapitału, dostrzegali już Adam Smith czy Johann von Thünen, pojęcie kapitał ludzki do kanonu słownictwa ekonomicznego na stałe weszło w drugiej połowie XX wieku dzięki pracom Jacoba Mincera ${ }^{1}$, Theodora W. Schulza ${ }^{2}$, i Garego S. Beckera ${ }^{3}$. Badania prowadzone nad czynnikami rozwoju gospodarczego wskazują na fakt, że różnice w akumulacji kapitału i pracy tłumaczą jedynie w 25-30\% zróżnicowania w poziomie PKB między krajami ${ }^{4}$. Pozostałych przyczyn wzrostu gospodarczego i rozwoju cywilizacyjnego upatruje się w czynnikach związanych z postępem technicznym oraz innowacyjnością, które w znacznej mierze zależą od ludzkich zdolności i kreatywności, będących w odróżnieniu od wkładu w proces produkcji, w postaci wysiłku fizycznego (czynnik produkcji, praca), traktowanych jako

* Adiunkt, Katedra Gospodarki Regionalnej i Środowiska, Wydział Ekonomiczno-Socjologiczny, Uniwersytet Łódzki. E-mail: sokol@uni.lodz.pl

${ }^{1}$ J. Mincer, Investment in Human Capital and Personal Income Distribution, Journal of Political Economy, Vol. 66, 1958, s. 281-302.

${ }^{2}$ T. W. Schultz, Investment in Human Capital, The American Economic Review, Vol. 51 (1), 1961, s. 1-17.

${ }_{3}^{3}$ G. Becker, Investment in Human Capital: A Theoretical Analysis, Journal of Political Economy, Vol. 70, 1962, s. 9-49.

${ }^{4}$ W. Orłowski, Knowledge Economy and Knowledge - Based Growth: Some Issues in a Transition Economy; [w:] The Knowledge-Based Economy. The European Challenges of the $21^{\text {st }}$ Century, A. Kukliński (red.), KBN, Warszawa 2000, s. 37 [za:] World Bank, Knowledge and Development. World Development Report, Oxford University Press 1998. 


\section{Wpływ korporacji transnarodowych na wzmacnianie kapitału ludzkiego...}

kapitał (ludzki). Ponadto, badania oparte na danych Banku Światowego, odnoszące się do relacji między poziomem edukacji a poziomem i stopą wzrostu gospodarczego, wskazują na zachodzącą między tymi zjawiskami dodatnią korelację ${ }^{5}$. Co istotne, badania empiryczne badające związki między kapitałem ludzkim a wzrostem gospodarczym na poziomie regionalnym prowadzą do wyników porównywalnych do badań realizowanych na poziomie międzynarodowym ${ }^{6}$.

Termin „kapitał ludzki” w najprostszym ujęciu oznacza zasób wartościowej i użytecznej wiedzy zdobytej w procesie kształcenia i praktyki zawodowej ${ }^{7}$. Jednakże, w literaturze przedmiotu pojęcie to pozostaje zdefiniowane w sposób niejednoznaczny lub nieprecyzyjny. Autorzy operują nim w różnych kontekstach, co w opinii S. R. Domańskiego pozostawia dość duże pole dla intuicyjnego interpretowania tego zagadnienia, ale $\mathrm{z}$ drugiej strony samo w sobie może być traktowania jako sposób jego definiowania ${ }^{8}$. Autor ten podejmuje próbę konkretyzacji definicji kapitału ludzkiego, traktując go jako „zasób wiedzy, umiejętności, zdrowia, energii witalnej zawarty w społeczeństwie. Zasób ten jest dany przez genetyczne cechy danej populacji raz na zawsze, ale można go powiększać drogą inwestycji w człowieka" ${ }^{9}$.

Według J. Grodzickiego natomiast, poprzez kapitał ludzki należy rozumieć „zasób wiedzy, umiejętności, zdolności, kwalifikacji, postaw, motywacji oraz zdrowia, o określonej wartości, będący źródłem przyszłych zarobków czy satysfakcji, przy czym jest on odnawialnym i stale powiększanym potencjałem ${ }^{10}$." Zdobyte umiejętności i kwalifikacje nie tylko wzbogacają intelektualnie jednostkę, ale znajdują konkretne przełożenie w postaci wysokości zarobków. Pogląd ten podziela J. Mincer, zdaniem którego można mówić o występowaniu zależności między wydłużeniem okresu edukacji a wzrostem wysokość płac osiąganych przez pracowników ${ }^{11}$.

${ }^{5}$ Zob. m.in. M. Herbst, Kapitat ludzki, dochód $i$ wzrost gospodarczy w badaniach empirycznych [w:] Kapitat ludzki i kapitat społeczny a rozwój regionalny, M. Herbst (red.), Wydawnictwo SCHOLAR, Warszawa 2007, s. 98-118.

${ }^{6}$ Zob. m.in. Herbst, M., Kapitat ludzki, dochód $i$ wzrost gospodarczy w badaniach empirycznych [w:] Kapitat ludzki i kapitat społeczny a rozwój regionalny, M. Herbst (red.), Wydawnictwo SCHOLAR, Warszawa 2007, s. 118-123.

${ }^{7}$ Oleksiuk A., Inwestowanie $w$ kapital ludzki $w$ Polsce, Wydawnictwo ECONOMICUS, Szczecin 2009, s. 9.

${ }^{8}$ Domański, S. R., Kapitał ludzki i wzrost gospodarczy, Wydawnictwo Naukowe PWN, Warszawa 1993, s. 16.

${ }^{9}$ Domański, S. R., Kapitat ludzki i wzrost gospodarczy, Wydawnictwo Naukowe PWN, Warszawa 1993, s. 19.

10 J. Grodzicki, Rola kapitalu ludzkiego w rozwoju gospodarki globalnej, Wydawnictwo Uniwersytetu Gdańskiego, Gdańsk 2003, s. 46.

${ }^{11}$ Mincer J., Schooling Experience and Learning, Columbia University Press, New YorkLondon 1974, s. 46. 
Dokonując przeglądu innych definicji kapitału ludzkiego warto wskazać na propozycję S. Walkiewicza, który zaproponował jego przedstawienie jako „wszystkie, ale to absolutnie wszystkie, zasoby niematerialne (przymioty) kojarzone $\mathrm{z}$ człowiekiem traktowanym jako samodzielna istota ludzka" ${ }^{12}$. W takim ujęciu, kapitał ludzki odróżnił od pozostałych typów kapitału, tj. finansowego, materialnego oraz społecznego ${ }^{13}$. S. Walukiewicz, dla wyjaśnienia istoty kapitału ludzkiego, posługuje się pięcioma obrazowymi przykładami ${ }^{14}$ :

- kapitałem ludzkim rozważanej osoby są jej szeroko rozumiane kompetencje i doświadczenie i to niezależnie od faktu, czy wykonuje ona w organizacji pracę twórczą czy rutynową;

- szeroko rozumiane wiedza i zdolności są bardzo istotnymi składowymi (częściami) kapitału ludzkiego danej osoby, szczególnie w jej pracy twórczej. Ogólnie wiedzę dzieli się na wiedzę skodyfikowaną (zawartą) w powszechnie dostępnych książkach, bibliotekach, bazach danych, archiwach itp. oraz na wiedzę spersonalizowana, którą posiada dana osoba lub stosunkowo wąski krag osób (np. dane wywiadu na określony temat). Z wiedzą spersonalizowaną silnie związane jest pojęcie zdolności i talentu (fenomenalna pamięć, absolutny słuch, atrakcyjny wygląd, zdolności artystyczne, aktorskie, przywódcze itp.);

- w niektórych profesjach (np. sportowych), bardzo ważną składową kapitału ludzkiego jest zdrowie i wydolność organizmu danej osoby;

- jest jeszcze stosunkowo liczna i różnorodna grupa elementów (składowych) kapitału ludzkiego, którą można określić zbiorczym terminem jako nastawienie życiowe do świata jako takiego. Są w tej grupie zarówno elementy pozytywne z punktu widzenia organizacji, takie jak optymizm, otwartość, prawdomówność itp., jak i negatywne, takie jak pesymizm, skrytość, hipokryzja itp.;

- z nastawienia życiowego należy wydzielić te elementy kapitału ludzkiego, które są bardzo ważne z punktu widzenia kapitału społecznego danej grupy/zespołu. Sa wśród nich takie składowe jak: zaufanie, tolerancja, lojalność, czyli elementy pozytywne nastawienia życiowego, jak i negatywne, takie jak podejrzliwość, kłótliwość, nielojalność itp.

${ }^{12}$ S. Walukiewicz, Kapitał ludzki. Skrypt akademicki, Instytut Badań Systemowych Polskiej Akademii Nauk, Warszawa 2010, s. 25.

${ }^{13} \mathrm{~S}$. Walukiewicz wskazuje, iż kapitał ludzki jest jedyną formą kapitału, która po zakończeniu pracy w firmie $\mathrm{F}$,,idzie” $\mathrm{z}$ danym pracownikiem do jego domu, podczas gdy kapitał finansowy, materialny i społeczny w firmie F (jego miejscu pracy) pozostaja (Walukiewicz S., Kapitat ludzki. Skrypt akademicki, Instytut Badań Systemowych Polskiej Akademii Nauk, Warszawa 2010, s. 25., s. 26).

${ }^{14}$ S. Walukiewicz, Kapitał ludzki. Skrypt akademicki, Instytut Badań Systemowych Polskiej Akademii Nauk, Warszawa 2010, s. 25-26. 
Należy podkreślić, że początkowo większość modeli ekonomicznych poświęconych zagadnieniu kapitału ludzkiego, w znacznej mierze abstrahowało od

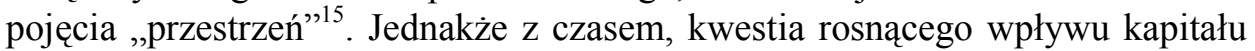
ludzkiego na rozwój gospodarczy upowszechniła się także w literaturze poświęconej zagadnieniom rozwoju lokalnego i regionalnego. $\mathrm{W}$ jej dorobku, terytorium (region) przestaje być utożsamiane jedynie z przestrzenią fizyczna, traktowaną w tradycyjnych teoriach lokalizacji gospodarczej w kategoriach kosztów ziemi, kapitału, siły roboczej czy kosztów transportu, a zaczyna być postrzegane jako „forma organizacji redukującej niepewność i ryzyko, stanowiącej źródło informacji, kumulowania i transferu wiedzy i umiejętności i jako źródło innowacyjności”. ${ }^{16}$

W tym kontekście, region postrzegany jest jako złożony system społecznogospodarczy, w którym wysoki poziom kapitału ludzkiego jest jednym z podstawowych warunków budowania otoczenia sprzyjającego dyfuzji wiedzy i kreowaniu innowacji, stanowiących źródło przewagi konkurencyjnej. W tym kontekście, kapitał ludzki przyczynia się do budowania tzw. regionów „uczących się", w których firmy zarówno produkcyjne, jak i usługowe, bez względu na ich strukturę i wielkość są konkurencyjne, ponieważ konkurencyjne jest całe terytorium w stosunku do otoczenia. Stanowi to konsekwencję zdolności, zlokalizowanych $\mathrm{w}$ danym miejscu przedsiębiorstw i innych organizacji, do działań innowacyjnych. Zdolność do innowacyjności jest natomiast efektem istnienia dobrze funkcjonującego systemu edukacji, zapewniającego wiedzę o charakterze formalnym oraz systemu wzajemnych powiązań między aktorami terytorium, kreującego wiedzę niekodyfikowaną, tzw. milczqca ${ }^{17}$. Szczególnie ten drugi typ wiedzy, reprezentowany przez różne formy zbiorowego uczenia się (uczenie się przez interakcje, uczenie się przez działanie itp.), potrafi zapewnić trwałą zdolność regionu dostosowywania się do zmieniającego się otoczenia.

${ }^{15}$ Szerzej: A. Nowakowska, Z. Przygodzki, M. E. Sokołowicz, Region w gospodarce opartej na wiedzy. Kapitat ludzki - innowacje - korporacje transnarodowe, Wydawnictwo Difin, Warszawa 2011, s. 50-55.

${ }^{16}$ I. Pietrzyk, Polityka regionalna Unii Europejskiej i regiony w państwach członkowskich, Wydawnictwo Naukowe PWN, Warszawa 2001, s. 20.

${ }^{17}$ M. E. Sokołowicz, Region wobec procesów globalizacji-terytorializacja przedsiębiorstw międzynarodowych (na przykładzie regionu tódzkiego), Prace Doktorskie z Zakresu Ekonomii i Zarządzania, Wydawnictwo Uniwersytetu Łódzkiego, Łódź 2008, s. 57. 


\section{Kapitał ludzki a aktywność przestrzenna KTN - analiza wzajemnych relacji}

Analizując wzajemne relacje między kapitałem ludzkim a aktywnością KTN $\mathrm{w}$ ujęciu terytorialnym, należy uwzględnić dwa wzajemne przenikające się aspekty, tj. z jednej strony analizę KL jako czynnika przyciagającego bezpośrednie inwestycje zagraniczne, a drugiej strony, identyfikację obszarów wpływu działalności dużych międzynarodowych przedsiębiorstw jako elementu wzmacniającego kapitał ludzki w regionie.

Kapitał ludzki staje się ważnym czynnikiem lokalizacji korporacji transnarodowych $(\mathrm{KTN})^{18}$ między innymi dlatego, że wraz ze wzrostem społecznogospodarczym i towarzyszącymi mu: wzrostem specjalizacji i stopnia złożoności gospodarek, rosną tzw. koszty transakcyjne ${ }^{19}$, w przeciwieństwie do kosztów produkcji ${ }^{20}$. Implikuje to dążenie do poszukiwania wysokich kompetencji, majacych na celu minimalizację tych kosztów.

Analogicznie do rosnącej liczby modeli ekonomicznych, uwzględniających znaczenie kapitału ludzkiego jako czynnika wzrostu gospodarczego, można wskazać przykłady wielu ilościowych badań ekonomicznych, wskazujących na rosnącą rolę tego kapitału zarówno w przyciaganiu bezpośrednich inwestycji zagranicznych, jak i określaniu ich charakteru. $\mathrm{Na}$ aspekt ten zwracał uwagę

18 Pojęcie „korporacja transnarodowa” odnosi się do przedsiębiorstw, prowadzących działalność w co najmniej dwóch krajach świata. Zgodnie z zaleceniami UNCTAD, KTN definiuje się jako przedsiębiorstwo będące spółką kapitałową składającą się z przedsiębiorstw macierzystych i ich filii zagranicznych. Za przedsiębiorstwo macierzyste uznaje się przy tym podmiot kontrolujacy aktywa innych firm w krajach poza krajem macierzystym, poprzez posiadanie udziału w ich kapitale własnym. Zagraniczna filia natomiast to spółka kapitałowa, w której inwestor ma udział, umożliwiający trwały wpływ na zarządzanie nim, przy czym za granice kontroli aktywów uważa się $10 \%$ zwykłych akcji lub prawo głosu w takim podmiocie gospodarczym (A. Zorska, Korporacje transnarodowe: przemiany, oddziaływania, wyzwania, Polskie Wydawnictwo Ekonomiczne, Warszawa 2007, s. 122). Według P. Dickena natomiast, KTN jest po prostu złożoną organizacją gospodarczą, która koordynuje działania tworzące wartość dodaną z jednego ośrodka podejmującego strategiczne decyzje (P. Dickens, Global Shift. Internationalization of Economic Activity, The Guilford Press, New York-London 1992, s. 226).

${ }^{19}$ Poza ceną płaconą za dobra podczas nabywania ich na rynku, strony zawieranych umów ponoszą także inne koszty (zwane transakcyjnymi), związane z poszukiwaniem kontrahentów, negocjowaniem warunków umowy, opłatami administracyjnymi, ubezpieczeniem transakcji, czy też ryzykiem niesolidności partnerów. Koszty transakcyjne stanowią przedmiot analizy szerokiego nurtu w ekonomii, zwanego ekonomią kosztów transakcyjnych, zapoczątkowaną przez R. Coase'a (R. Coase, The nature of the firm, Economica 1937, 4 (16), s. 386-405) i rozwinięta przez O. Williamsona (O. Williamson, Market and hierarchies. Analysis and Antitrust Implications, Free Press, Nowy Jork 1975). Szeroki jej opis w literaturze polskiej dostępny jest w opracowaniu: Hardt, Ł., Ekonomia kosztów transakcyjnych - geneza i kierunki rozwoju, Wydawnictwo Uniwersytetu Warszawskiego, Warszawa 2009.

${ }^{20}$ T. Pakulska, M. Poniatowska-Jaksch, Globalne pozyskiwanie zasobów - zarys problemu, Gospodarka Narodowa, 1-2, 2008, s. 26. 
między innymi J. R. Lucas wskazując, że brak odpowiedniego poziomu kapitału ludzkiego stanowiło jedną z istotnych przyczyn zniechęcających do podejmowania BIZ w krajach słabiej rozwiniętych ${ }^{21}$. J. H. Dunning podkreślił natomiast, iż umiejętności oraz poziom wykształcenia siły roboczej wpływa jednocześnie na poziom, jak i na rodzaj działalności, podejmowanych przez KTN w krajach goszczących $^{22}$. Szerszy przegląd literatury poświęconej badaniom nad znaczeniem kapitału ludzkiego jako czynnika lokalizacji BIZ badań, podejmujący analizy na poziomie gospodarek narodowych oraz porównań międzynarodowych, dostępny jest $\mathrm{m}$. in. w opracowaniu F. Noorbakhsha i inych ${ }^{23}$.

Współczesne przedsiębiorstwa, w tym także korporacje transnarodowe, poszukują na rynku pracy dwóch typów pracowników. Pierwszą grupę stanowi wysoko wykwalifikowana kadra reprezentująca możliwie najwyższy poziom kapitału ludzkiego (inżynierowie, menedżerowie, naukowcy), do drugiej grupy należą pracownicy wykonujący prace rutynowe i usługowe. Optymalne miejsce dla działalności nowoczesnych przedsiębiorstw to takie, które $\mathrm{z}$ jednej strony posiada cechy przyciagające osoby wykwalifikowane, a z drugiej strony stwarza korzystne warunki dla działalności gospodarczej, poprzez wzmacnianie poziomu kapitału ludzkiego w rozumieniu ogólnym. Wśród najważniejszych form inwestycji w kapitał ludzki wymienia się $e^{24}$ :

- wydatki na ochronę zdrowia, wpływające na długość życia i siłę witalną jednostek ludzkich;

- szkolenia w czasie pracy zawodowej;

- kształcenie na wszystkich szczeblach edukacji, w tym również coraz istotniejsze kształcenie ustawiczne osób dorosłych;

- migracje ludności ukierunkowane na poszukiwanie pracy, której znalezienie umożliwia waloryzację kapitału ludzkiego (a zatem pośrednio także inwestycje we wszelki materialne i niematerialne czynniki zwiększające poziom mobilności ludzi);

- poszukiwanie informacji o sytuacji ekonomicznej form i perspektywach zawodowych;

- badania naukowe.

W powyższych obszarach oddziaływania, na skutek postępujących procesów decentralizacji władzy, powszechnych w znakomitej większości zarówno krajów rozwiniętych, jak i rozwijających się, dostrzega się rosnącą rolę regionów jako

${ }^{21}$ R. E. Lucas, Jr, Why Doesn't Capital Flow from Rich to Poor Countries, American Economic Review, no. 89, 1990, s. 92-96.

22 J. H. Dunning, Explaining International Production, Unwin Hyman, Londyn 1988.

${ }^{23}$ Noorbakhsh, F., Paloni, A., Youssef, A., Human Capital and FDI Inflows to Developing Countries: New Empirical Evidence, World Development, Vol. 29, no. 9, 2001, s. 1595-1596.

${ }^{24}$ Por. S. R. Domański, Kapital ludzki i wzrost gospodarczy, Wydawnictwo Naukowe PWN, Warszawa 1993, s. 20. 
ważnych podmiotów mogących przyczyniać się do wzmacniania kapitału ludzkiego. Od ich aktywnej roli w tym obszarze, zależy w znacznej mierze poziom atrakcyjności regionu, jako miejsca działalności gospodarczej w sytuacji, w której poziom kapitału ludzkiego traktowany jest jako jeden z najważniejszych czynników sukcesu przedsiębiorstw.

Należy jednak podkreślić, że tkwiące w jednostkach ludzkich wiedza, umiejętności, postawy, czy siły witalne nie tylko stanowią istotny walor lokalizacyjny, lecz mogą być także wzmacniane przez działalność korporacji. Wśród wielu potencjalnych korzyści, wskazywanych $\mathrm{w}$ analizach poświęconych wpływowi bezpośrednich inwestycji zagranicznych ${ }^{25}$ na rozwój krajów i regionów je przyjmujących, wymienia się transfer technologii. Odbywa się on przy tym przede wszystkim w formie ${ }^{26}$ :

- materialnej, w postaci dóbr stanowiących wkład rzeczowy (aport) inwestorów w realizowane przedsięwzięcie oraz importu zaopatrzeniowego związanego z realizacją inwestycji;

- niematerialnej, obejmującej wiedzę techniczno-organizacyjną, odgrywającą ważną role w rozwoju przedsiębiorstwa;

- inwestycji w kapitał ludzki, polegających m. in. na doskonaleniu kwalifikacji pracowników poprzez organizowanie różnego rodzaju szkoleń oraz na zatrudnianiu specjalistów pochodzących z macierzystego kraju inwestora.

Tym samym w sytuacji, gdy BIZ przyczyniają się do transferu technologii do krajów i regionów je przyjmujących, wytwarza się pośredni związek z podnoszeniem jakości kapitału ludzkiego. Wiąże się to z faktem, że w takiej sytuacji transferowany jest zwykle kompletny pakiet korzyści - od dóbr kapitałowych, poprzez przemysłowe prawa własności, po know-how oraz zakumulowane doświadczenia i umiejętności w organizacji, zarządzaniu i marketingu ${ }^{27}$.

${ }^{25}$ Proces międzynarodowej ekspansji korporacji transnarodowych odbywa się przede wszystkim $\mathrm{w}$ formie przejęć udziałów w istniejących już przedsiębiorstwach w innych krajach (ang. brownfield investment) lub też $\mathrm{w}$ formie tworzenia $\mathrm{w}$ tych krajach od podstaw nowych podmiotów gospodarczych (ang. greenfield investment). Tym samym uznać należy, że choć równie istotnym obszarem aktywności gospodarczej KTN pozostają także różnorodne kooperacyjne formy rozwoju (tzw. joint ventures lub alianse strategiczne), warunkiem uznania danego przedsiębiorstwa za transnarodową korporację pozostaje podjęcie przez nie aktywności w postaci bezpośredniej inwestycji zagranicznej (BIZ) w co najmniej jednym (innym niż macierzysty) kraju na świecie (szerzej w: Grzegorczyk W., Strategie wejścia polskich przedsiębiorstw na rynki zagraniczne, Wydawnictwo Stardruk, Warszawa 2006, s. 42-63; A. Nowakowska, Z. Przygodzki, M. E. Sokołowicz, Region w gospodarce opartej na wiedzy. Kapitat ludzki - innowacje - korporacje transnarodowe, Wydawnictwo Difin, Warszawa 2011, s. 160-169).

${ }^{26}$ C. Pilarska, Bezpośrednie inwestycje zagraniczne a transfer technologii [w:] Bezpośrednie inwestycje zagraniczne $w$ Polsce, W. Karaszewski (red.), Wydawnictwo Uniwersytetu Mikołaja Kopernika, Torun 2003, s. 289-290.

${ }^{27}$ A. Donakowski, Wptyw bezpośrednich inwestycji zagranicznych na transfer technologii do polskiej gospodarki [w:] Bezpośrednie inwestycje zagraniczne w Polsce, W. Karaszewski (red.), Wydawnictwo Uniwersytetu Mikołaja Kopernika, Torun 2003, s. 314-315. 
20 Wpływ korporacji transnarodowych na wzmacnianie kapitału ludzkiego...

Analizując wpływ działalności korporacji, realizujących swoje strategie rozwojowe $\mathrm{w}$ formie bezpośrednich inwestycji zagranicznych, na jakość kapitału ludzkiego, należy uwzględnić także ich bezpośredni oraz pośredni wpływ na rynki pracy w wymiarze ilościowym oraz jakościowym. Warto zauważyć, że w każdym z tych wymiarów dostrzec można zarówno szanse, jak i zagrożenia dla lokalnych rynków pracy, a w związku z nimi również dla jakości kapitału ludzkiego (por. tabela 1). W przypadku ilościowych efektów wpływu BIZ na poziom zatrudnienia, przewidywać można bowiem zarówno możliwość tworzenia nowych miejsc pracy na skutek napływu kapitału (przede wszystkim w przypadku inwestycji realizowanych od podstaw), jak i wskazywać na ryzyko redukcji miejsc pracy, np. na skutek przejmowania lokalnych przedsiębiorstw przez filie i przedstawicielstwa korporacji.

Tabela 1. Potencjalne efekty wpływu bezpośrednich inwestycji zagranicznych na wielkość, jakość i lokalizację zatrudnienia w kraju przyjmującym

\begin{tabular}{|c|c|c|c|c|}
\hline \multirow{3}{*}{$\begin{array}{l}\text { Obszar } \\
\text { wpływu }\end{array}$} & \multicolumn{4}{|c|}{ Efekty bezpośrednich inwestycji zagranicznych } \\
\hline & \multicolumn{2}{|c|}{ bezpośrednie } & \multicolumn{2}{|c|}{ pośrednie } \\
\hline & pozytywne & negatywne & pozytywne & negatywne \\
\hline Wielkość & $\begin{array}{l}\text { Na skutek napły- } \\
\text { wu dodatkowego } \\
\text { kapitału, powsta- } \\
\text { ją nowe miejsca } \\
\text { pracy }\end{array}$ & $\begin{array}{l}\text { BIZ polegające na } \\
\text { przejęciu lokalnego } \\
\text { przedsiębiorstwa, mogą } \\
\text { wiązać się z redukcją } \\
\text { miejsc pracy w wyniku } \\
\text { jego restrukturyzacji }\end{array}$ & $\begin{array}{l}\text { BIZ sprzyjają po- } \\
\text { wstawaniu nowych } \\
\text { miejsc pracy w } \\
\text { przedsiębiorstwach } \\
\text { kooperujących z } \\
\text { zagranicznym inwe- } \\
\text { storem (efekty } \\
\text { mnożnikowe) }\end{array}$ & $\begin{array}{l}\text { Nastawienie firm } \\
\text { zagranicznych na } \\
\text { zaopatrzenie przez } \\
\text { import, a nie na } \\
\text { lokalnych dostaw- } \\
\text { ców, może powo- } \\
\text { dować utratę } \\
\text { miejsc pracy w } \\
\text { firmach lokalnych }\end{array}$ \\
\hline Jakośćć & $\begin{array}{l}\text { BIZ sprzyjają } \\
\text { zwiększaniu } \\
\text { poziomu płac } \\
\text { oraz wydajności } \\
\text { pracy }\end{array}$ & $\begin{array}{l}\text { BIZ wprowadzają nowe } \\
\text { standardy i praktyki, } \\
\text { często nie akceptowane } \\
\text { przez pracowników } \\
\text { (np. nastawione na silną } \\
\text { konkurencję między } \\
\text { zatrudnionymi, systemy } \\
\text { wynagradzania pracy) } \\
\end{array}$ & $\begin{array}{l}\text { BIZ sprzyjają roz- } \\
\text { przestrzenianiu } \\
\text { „najlepszych prak- } \\
\text { tyk”, w zakresie } \\
\text { nowoczesnych } \\
\text { metod organizacji } \\
\text { produkcji w firmach } \\
\text { lokalnych } \\
\end{array}$ & $\begin{array}{l}\text { Istnieje prawdopo- } \\
\text { dobieństwo obniżki } \\
\text { poziomu płac w } \\
\text { sytuacji, gdy lokal- } \\
\text { ne formy podejmu- } \\
\text { ją konkurencję } \\
\text { cenową z nowym } \\
\text { inwestorem } \\
\end{array}$ \\
\hline $\begin{array}{l}\text { Lokaliza- } \\
\text { cja }\end{array}$ & $\begin{array}{l}\text { BIZ stwarzają } \\
\text { nowe miejsca } \\
\text { pracy w regio- } \\
\text { nach zagrożonych } \\
\text { lub dotkniętych } \\
\text { wysokim bezro- } \\
\text { bociem }\end{array}$ & $\begin{array}{l}\text { BIZ powodują dalszy } \\
\text { napływ liczby ludności } \\
\text { do już zatłoczonych } \\
\text { aglomeracji; pogłębiają } \\
\text { nierówności regionalne }\end{array}$ & $\begin{array}{l}\text { BIZ zachęcają } \\
\text { przenoszeniu się } \\
\text { innych firm - do- } \\
\text { stawców - do miej- } \\
\text { sca lokalizacji } \\
\text { inwestycji bezpo- } \\
\text { średniej }\end{array}$ & $\begin{array}{l}\text { Sytuacja, w której } \\
\text { inwestor zagra- } \\
\text { niczny substytuuje } \\
\text { lokalną produkcję } \\
\text { i polega bardziej na } \\
\text { importerach, może } \\
\text { doprowadzić do } \\
\text { upadku lub deloka- } \\
\text { lizacji firm lokal- } \\
\text { nych }\end{array}$ \\
\hline
\end{tabular}

Źródło: UNCTAD, World Investment Report, ONZ, Nowy Jork-Genewa 1994, s. 167. 
W zakresie pośrednich efektów wpływu na rynki pracy w wymiarze ilościowym sytuacja prezentować może się w podobny sposób, ponieważ na skutek wzrostu poziomu kooperacji zagranicznych inwestorów bezpośrednich z lokalnymi przedsiębiorstwami, można spodziewać się wzrostu poziomu zatrudnienia $\mathrm{w}$ tych ostatnich, jednak powstaje również zagrożenie $\mathrm{w}$ przypadku sytuacji odwrotnej. Spadek poziomu zatrudnienia w przedsiębiorstwach lokalnych może mieć bowiem miejsce wówczas, gdy na skutek większej chęci kooperowania inwestorów z dostawcami z innych krajów, wystapi efekt substytucji lokalnej produkcji poprzez import. W skrajnych sytuacjach oznaczać to może zagrożenie dla rozwoju kapitału ludzkiego, na skutek rosnącego ogólnego poziomu bezrobocia $\mathrm{w}$ regionie.

W ujęciu jakościowym bezpośrednie inwestycje zagraniczne realizowane przez korporacje, mogą z jednej strony sprzyjać zwiększaniu poziomu płac oraz wydajności pracy, natomiast $\mathrm{z}$ drugiej strony, generować ryzyko wprowadzania nowych praktyk, niekorzystnych z punktu widzenia lokalnych pracowników, takich jak systemy motywacyjne nastawione na konkurencję i ograniczające tym samym poziom zaufania między pracownikami, czy też upowszechnienie się tzw. umów „śmieciowych”, tj. ukierunkowanych przede wszystkim na eksploatację siły roboczej, bez zapewnienia pracownikom minimum osłon socjalnych oraz możliwości rozwoju zawodowego.

Pośredni wpływ BIZ na jakość funkcjonowania rynków pracy może natomiast wiązać się z rozprzestrzenianiem się dobrych praktyk, przede wszystkim $\mathrm{w}$ formie transferu wiedzy $\mathrm{i}$ umiejętności będących $\mathrm{w}$ posiadaniu pracowników filii i przedstawicielstw KTN, do załóg pracowniczych współpracujących z nimi przedsiębiorstw lokalnych. Wymiaru negatywnego tych efektów należy natomiast upatrywać np. w przypadku ryzyka obniżki poziomu płac w przedsiębiorstwach lokalnych, na skutek podejmowania przez nie konkurencji cenowej $\mathrm{z}$ nowym inwestorem.

Podsumowaniem powyższych rozważań może być odwołanie się do A. Zorskiej, która do głównych, korzystnych efektów jakościowych BIZ w dziedzinie zatrudnienia zalicza ${ }^{28}$ :

- podnoszenie kwalifikacji pracowników zatrudnionych w filiach dzięki szkoleniom zawodowym, specjalistycznym, językowym, informatycznym itd.;

- szkolenie pracowników zatrudnionych u lokalnych poddostawców i podwykonawców, dla zagwarantowania jakości dostaw półproduktów i usług;

- stosunkowo dobre wynagrodzenie krajowej siły roboczej;

- stosowanie bardziej efektywnych instrumentów zarządzania zasobami ludzkimi;

${ }^{28}$ Zorska A., Korporacje transnarodowe: przemiany, oddziaływania, wyzwania, Polskie Wydawnictwo Ekonomiczne, Warszawa 2007, s. 289. 
- stworzenie lepszych warunków pracy, m. in. wyposażenie w maszyny, urządzenia, sprzęt biurowy itd.;

- znacznie wyższą wydajność pracy w stosunku do przedsiębiorstw krajowych;

- zmianę istniejącej struktury zatrudnienia i kwalifikacji w gospodarce kraju goszczącego (w kierunku dziedzin preferowanych przez obcych inwestorów);

- ukierunkowanie kształcenia się i dokształcania na możliwość zatrudnienia w filiach firm zagranicznych;

- tworzenie „transnarodowej elity”, czyli grupy miejscowych pracowników o najwyższych kwalifikacjach i dochodach, o stylu pracy i życia zgodnym z kulturą organizacji największych KTN.

Dostrzeżenie, że wpływ korporacji na rynki pracy oraz na poziom rozwoju kapitału ludzkiego może generować korzyści i straty, nakazuje podkreślić, że ostateczny ich bilans będzie zależał od takich istotnych czynników, jak strategie międzynarodowych korporacji (które interesu ekonomicznego upatrywać mogą nie w prostej eksploatacji zasobów, lecz w utrzymywaniu względnie trwałej przewagi konkurencyjnej), czy też poziom rozwoju regionów jako atrakcyjnych miejsc lokalizacji działalności gospodarczej. Istotnym czynnikiem warunkującym ten bilans pozostaje ponadto polityka państw i regionów w zakresie przyciągania kapitału zagranicznego, przede wszystkim w kontekście wyważenia chęci przyciągania BIZ, poprzez oferowanie inwestorom pakietów ulg inwestycyjnych, ze spodziewanymi korzyściami $\mathrm{w}$ obszarze nie tylko kreowania nowych miejsc pracy, ale przede wszystkim transferu technologii oraz podnoszenia poziomu kapitału ludzkiego.

Z powyższych powodów, aby KTN przyczyniały się do rozwoju regionu, nie mogą pozostawać jedynym lub dominującym podmiotem produkującym nową wiedzę i innowację, przyczyniającym się do różnicowania struktury gospodarczej i waloryzującym kapitał ludzki w regionie. KTN muszą także odnosić korzyści ze współpracy z lokalnym środowiskiem przedsiębiorczości. Aby jednak warunek ten został spełniony, środowisko takie musi już istnieć w regionie lub być $\mathrm{w}$ fazie tworzenia. W opinii autora stanowi to istotne zadanie dla sektora publicznego, który w tym obszarze powinien inwestować w:

- potencjał innowacyjny oparty na badaniach i rozwoju zaawansowanych technologii;

- $\quad$ system transferu technologii ze sfery nauki do sfery biznesu;

- system promowania korzyści ze współpracy między przedsiębiorstwami w ramach tzw. klastrów ${ }^{29}$;

${ }^{29}$ Klastry to zakorzenione terytorialnie skupiska wzajemnie powiązanych firm, wyspecjalizowanych dostawców i usługodawców, firm działających w pokrewnych sektorach i związanych 
- jakość kapitału ludzkiego ${ }^{30}$.

Spełnienie powyższych warunków prowadziłoby do stwierdzenia, że w regionie istnieje system innowacji, gotowy na „przyjęcie” takich korporacji, których strategie stwarzają szanse na wzmocnienie kapitału ludzkiego w regionie. Dobrze funkcjonujące regionalne systemy innowacji to takie systemy terytorialne, w których przepływy informacji i wiedzy przyczyniają się do budowy niematerialnych zasobów specyficznych regionu. Zasoby te tworzą szeroko pojęty kontekst instytucjonalny ${ }^{31}$ prowadzenia działalności gospodarczej, na który składają się wspólne wartości, reguły gry i schematy interpretacyjne (przez A. Marshalla nazwane ,atmosferą przemysłową ${ }^{32}$ ). Należy przy tym zauważyć, że relacje między kapitałem ludzkim w regionie a regionalnym zasobami specyficznymi pozostają dwukierunkowe. Budowanie długookresowej przewagi konkurencyjnej regionu w oparciu o zasoby niematerialne, staje się bowiem zarówno uzależnione od wysokiej jakości kapitału ludzkiego, jak również ich ewolucja może stymulować jego waloryzację.

Budowanie kapitału ludzkiego w formie pośredniej, tj. na styku relacji filii KTN z otoczeniem regionalnym, odnosi się do konieczności analizy powiązań kooperacyjnych korporacji z lokalnymi podmiotami gospodarczymi. E. Taymaz $\mathrm{i}$ in. prezentują trzy podejścia do relacji, jakie przedstawicielstwo korporacji transnarodowej może budować ze swymi lokalnymi odbiorcami i dostawcami ${ }^{33}$. Pierwsze z proponowanych podejść, nazwane przez Autorów „dualistycznym”, zakłada nierówny podział sił, wynikający ze zróżnicowanej pozycji przetargowej

z nimi instytucji (na przykład uniwersytetów, jednostek normalizujących, stowarzyszeń branżowych, instytucji wspierających) w poszczególnych dziedzinach, konkurujących między sobą ale również współpracujących (M.E. Porter, On Competition, Harvard University Press, Boston 2008, s. 213-214). Klastry stanowią specyficzną formę organizacji produkcji, polegającą na koncentracji w bliskiej przestrzeni elastycznych przedsiębiorstw prowadzących komplementarną działalność gospodarczą. Podstawą ich funkcjonowania są zatem powiązania kooperacyjne generujące procesy powstawania specyficznej wiedzy oraz zwiększające zdolności adaptacyjne (por. A. Nowakowska, A. Bąkowski, Klaster [w:] Innowacje i transfer technologii. Stownik pojęć, K. B. Matusiak (red.), Polska Agencja Rozwoju Przedsiębiorczości, Warszawa 2008, s. 80-83).

${ }^{30}$ Por. N. A. Phelps, Cluster or Capture? Manufacturing Foreign Direct Investment, External Economies and Agglomeration, Regional Studies, Vol. 48, issue 4, 2008, s. 463.

${ }^{31} \mathrm{Na}$ kontekst ten składają się instytucje o różnorodnym charakterze (zarówno formalne, jak i nieformalne), określające tzw. „reguły gry” życia społeczno-gospodarczego, przyczyniając się tym samym do redukowania niepewności działalności gospodarczej $\mathrm{w}$ warunkach zmiennego otoczenia, definiowania zasad kooperacji między przedsiębiorstwami i innymi aktorami regionalnego systemu innowacji oraz stwarzając motywację do podejmowania działań innowacyjnych (Ch. Edquist, B. Johnson, Institutions and Organizations in System of Innovation [w:] Systems of Innovations: Technologies, organizations, and institutions, Ch. Edquist (red.), Printer Publishers/Cassel Academic, London 1997, s. 51-55).

${ }^{32}$ A. Marshall, Principles of Economics, Macmillan, London 1920.

${ }^{33}$ E. Taymaz, Y. Kiliçaslan, Determinants of Subcontracting and Regional Development: An Empirical Study on Turkish Textile and Engineering Industries, Regional Studies, Vol. 39.5, s. $635-636$. 
24 Wpływ korporacji transnarodowych na wzmacnianie kapitału ludzkiego...

„małego dostawcy” i „dużego odbiorcy”. Z tego powodu, lokalne firmy z sektora MŚP są zwykle „eksploatowane” przez dużego zamawiającego, który zapewnia sobie $\mathrm{w}$ ten sposób elastyczność działania poprzez outsourcing pewnych elementów swego łańcucha dostaw oraz redukcję kosztów działalności gospodarczej. Wspominany „dualizm” dotyczy przy tym także rynków pracy, gdzie pracownicy sektora MŚP bywają zazwyczaj gorzej opłacani niż pracownicy dużych korporacji a ponadto są gorzej wykształceni i funkcjonują w gorszych warunkach pracy, co ogranicza możliwości rozwoju kapitału ludzkiego.

Tabela 2. Klasyfikacja podejść do relacji KTN ze środowiskiem w regionie

\begin{tabular}{|l|l|l|l|}
\hline & \multicolumn{1}{|c|}{ Podejście dualistyczne } & \multicolumn{1}{|c|}{$\begin{array}{c}\text { Podejście } \\
\text { rozwojowe }\end{array}$} & \multicolumn{1}{|c|}{$\begin{array}{c}\text { Podejście } \\
\text { sieciowe }\end{array}$} \\
\hline Jednostka analizy & $\begin{array}{l}\text { Relacja między dostawcą a } \\
\text { odbiorca }\end{array}$ & $\begin{array}{l}\text { Relacja między do- } \\
\text { stawcą a odbiorcą }\end{array}$ & $\begin{array}{l}\text { Grupa współpra- } \\
\text { cujących ze sobą } \\
\text { przedsiębiorstw }\end{array}$ \\
\hline Charakter dostaw & $\begin{array}{l}\text { Eksploata- } \\
\text { cja/podporządkowanie }\end{array}$ & $\begin{array}{l}\text { Zależność/nacisk na } \\
\text { rozwój }\end{array}$ & Równorzędność \\
\hline $\begin{array}{l}\text { Kierunki relacji: } \\
\text { odbiorca } \\
\text { dostawca }\end{array}$ & $\begin{array}{l}\text { Aktywna } \\
\text { Pasywna }\end{array}$ & $\begin{array}{l}\text { Aktywna } \\
\text { Pasywna }\end{array}$ & $\begin{array}{l}\text { Aktywna } \\
\text { Aktywna }\end{array}$ \\
\hline $\begin{array}{l}\text { Wielkość } \\
\text { odbiorcy } \\
\text { dostawcy }\end{array}$ & $\begin{array}{l}\text { Duży } \\
\text { Mały }\end{array}$ & $\begin{array}{l}\text { Duży } \\
\text { Mały }\end{array}$ & $\begin{array}{l}\text { Mały lub duży } \\
\text { Mały lub duży }\end{array}$ \\
\hline $\begin{array}{l}\text { Poziom zaawan- } \\
\text { sowania technolo- } \\
\text { gicznego: } \\
\text { odbiorcy } \\
\text { dostawcy }\end{array}$ & $\begin{array}{l}\text { Wysoki } \\
\text { Niski }\end{array}$ & $\begin{array}{l}\text { Wysoki } \\
\text { Niski, ale dostosowu- } \\
\text { jaccy się do wymagań } \\
\text { odbiorcy }\end{array}$ & $\begin{array}{l}\text { Wysoki lub średni } \\
\text { Wysoki lub średni }\end{array}$ \\
\hline $\begin{array}{l}\text { Cele ekonomiczne: } \\
\text { odbiorcy }\end{array}$ & $\begin{array}{l}\text { Elastyczność, minimalizacja } \\
\text { kosztów, transfer ryzyka przez } \\
\text { outsourcing }\end{array}$ & $\begin{array}{l}\text { Koncentracja na klu- } \\
\text { czowych kompeten- } \\
\text { cjach (core business) } \\
\text { Dostęp do rynków i } \\
\text { technologii }\end{array}$ & $\begin{array}{l}\text { Wspólne podno- } \\
\text { szenie wydajności } \\
\text { i elastyczność }\end{array}$ \\
$\begin{array}{l}\text { Występowanie w charakterze } \\
\text { dostawcy jako głowy cel } \\
\text { istnienia }\end{array}$ & $\begin{array}{l}\text { Wspólne podno- } \\
\text { szenie wydajności } \\
\text { i elastyczność }\end{array}$ \\
\hline $\begin{array}{l}\text { Projektowanie } \\
\text { produktów i proce- } \\
\text { sów }\end{array}$ & $\begin{array}{l}\text { Dostosowane do wymagań } \\
\text { odbiorcy }\end{array}$ & $\begin{array}{l}\text { Dostosowane do wy- } \\
\text { magan odbiorcy } \\
\text { darkę }\end{array}$ & $\begin{array}{l}\text { Negocjowane } \\
\text { między dostawca } \\
\text { i odbiorcą }\end{array}$ \\
\hline $\begin{array}{l}\text { Reprodukcja relacji duali- } \\
\text { stycznych }\end{array}$ & $\begin{array}{l}\text { Unowocześnienie } \\
\text { gospodarki }\end{array}$ & $\begin{array}{l}\text { Wzajemne ucze- } \\
\text { nie się i wzrost }\end{array}$ \\
\hline
\end{tabular}

Źródło: E. Taymaz, Y. Kiliçaslan, Determinants of Subcontracting and Regional Development: An Empirical Study on Turkish Textile and Engineering Industries, Regional Studies, Vol. 39.5, s. 635. 
W podejściu „rozwojowym”, choć także zakłada się dychotomię, to jednak silniej akcentuje się pozytywną rolę relacji pomiędzy sektorem lokalnym sektorem MŚP a KTN. Wskazuje się zatem, że występowanie dużej korporacji w charakterze poddostawcy zwiększa szanse przedsiębiorstw z sektora MSP na wzrost zatrudnienia, absorbowanie technologii a także eksport. Warto podkreślić, iż w dużych firmach ponadnarodowych innowacje powstają coraz częściej jako efekt „zdecentralizowanej specjalizacji”, tj. umiejętności wypracowania takiej strategii korporacyjnej, która potrafi koncentrować się na kluczowych umiejętnościach (tworzonych wewnątrz struktury organizacyjnej KTN), a jednocześnie czerpać korzyści ze współpracy z tzw. „wyspami wiedzy”, czyli najbardziej innowacyjnymi regionalnymi systemami innowacji, zlokalizowanymi w różnych miejscach na świecie ${ }^{34}$. W tym rozumieniu KTN mogą wzmacniać kluczowe kompetencje, poprzez funkcjonowanie jako swoiste ,pasy transmisyjne" wiedzy milczącej, łączące dynamicznie rozwijające się regionalne systemy innowacji. Systemy te mogą tym samym współegzystować ze strukturami hierarchicznymi korporacji, szczególnie w obszarze zarządzania tą działalnością, która choć pozostaje istotna dla budowania konkurencyjności korporacji - nie będąc działalnością kluczową - może być przedmiotem np. outsourcingu lub być realizowana poprzez inne formy partnerstwa z lokalnymi przedsiębiorstwami i instytucjami ${ }^{35}$.

Ostatni z modeli proponowanych przez Autorów, oparty jest natomiast na podejściu sieciowym. Zakłada on występowanie relacji o równorzędnej sile przetargowej partnerów (udział dużych firm w takim systemie nie jest konieczny) i co istotne, relacje te nie są relacjami dwustronnymi, ale sieciowymi (istnieje wiele różnokierunkowych powiązań między aktorami lokalnymi). Z funkcjonowania w sieci, firmy z sektora MŚP zyskują wiele korzyści, wśród których wymienić należy:

- korzyści skali osiagane dzięki budowaniu powiązań poziomych w danym sektorze rynku;

- korzyści wynikające ze specjalizacji i podziału pracy, uzyskiwane dzięki budowaniu powiązań pionowych w ramach łańcucha wartości dodanej;

- podnoszenie poziomu innowacyjności dzięki korzystaniu ze zjawiska rozprzestrzeniania się informacji w ramach sieci;

${ }^{34}$ Zob. np. A. Amin, P. Cohendet, Learning and Adaptation in Decentralised Business Networks, Environment and Planning D: Society and Space, 17, 1999, s. 87-104; N. Nohria, Ghoshal S., The Differentiated Network: Organizing Multinational Corporations for Value Creation, Jossey-Bass Publishers, San Francisco 1997.

${ }^{35}$ A. Nowakowska, Z. Przygodzki, M. E. Sokołowicz, Region w gospodarce opartej na wiedzy. Kapitat ludzki - innowacje - korporacje transnarodowe, Wydawnictwo Difin, Warszawa 2011, s. 173. 
- dostęp do zasobów pozostających w dyspozycji instytucji otoczenia biznesu i innych instytucji sektora publicznego, jeśli te także stają się elementami sieci powiązań biznesowych.

W podsumowaniu rozważań na temat wpływu działalności dużych ponadnarodowych podmiotów gospodarczych na poziom rozwoju kapitału ludzkiego, można odwołać się do konkluzji sformułowanej w roku 2000 przez międzynarodową agendę OZN UNCTAD (Konferencja Narodów Zjednoczonych ds. Handlu i Rozwoju), odpowiedzialną za koordynację działalności międzynarodowej w dziedzinie współpracy gospodarczej, regionalnej i polityki rozwojowej. W wyniku wieloletnich badań podejmowanych na zlecenie UNCTAD stwierdzono, że choć w znakomitej większości przypadków korporacje wykazują większą tendencję do inwestowania w rozwój kompetencji i umiejętności lokalnych pracownika, w stopniu wyższym niż przedsiębiorstwa rodzime, to mimo wszystko kraje goszczące nie powinny w tym zakresie polegać jedynie na KTN. Zwyczajowo bowiem, korporacje transmitują do krajów i regionów goszczących technologie dostosowane do „zastanego” poziomu kapitału ludzkiego i zależy im przede wszystkim na kształceniu wydajnych operatorów tych technologii. Relatywnie rzadko decydują się natomiast na stymulowanie w krajach goszczących, rozwoju kapitału ludzkiego na poziomie najwyższym, tj. zapewniającym rozwój najnowszej wiedzy i technologii, ,rezerwując” je dla krajów i regionów ich pochodzenia. Innymi słowy, wzmocnienie ogólnego poziomu umiejętności i zapewnienie wysokiego poziomu szkolenia specjalistycznego jest czymś, co kraje i regiony przyjmujące czynią $\mathrm{z}$ własnej inicjatywy. W długim okresie natomiast, takie strategie mogą skutkować przyciaganiem inwestycji zagranicznych o wyższej jakości oraz skłonić obecnych inwestorów do podejmowania bardziej wyrafinowanych strategii rozwojowych ${ }^{36}$.

\section{Współzależności między działalnością korporacji transna- rodowych a kapitałem ludzkim w świetle badań w Łódzkim Obszarze Metropolitalnym}

Wpływ działalności korporacji transnarodowych na umiędzynarodowienie gospodarki w ujęciu regionalnym, ma szczególnie istotne znaczenie dla dużych obszarów zurbanizowanych, uznawanych za metropolie lub do miana metropolii pretendujących. Poziom otwarcia gospodarki na otoczenie międzynarodowe nie stanowi przy tym dopełnienia, ale podstawowy warunek zaklasyfikowania jednostki osadniczej jako metropolii. Odwołując się do analiz ESPON, wskazują-

${ }^{36}$ UNCTAD, The Competitiveness Challenge: Transnational Corporations and Industrial Restructuring in Developing Countries, Geneva 2000, s. 17. 
cych na pięć podstawowych funkcji metropolitalnych ${ }^{37}$, otwarcie na BIZ przyczynia się wzmacniania czterech $\mathrm{z}$ nich. W naturalny sposób wiąże się bowiem z goszczeniem filii i przedstawicielstw korporacji transnarodowych (funkcja decyzyjna), wymusza inwestycje w infrastrukturę zwiększająca jej międzynarodową dostępność (funkcja komunikacyjna), poprzez transfer technologii przyczynia się do wzmocnienia potencjału innowacyjnego danego obszaru (funkcja wiedzy) oraz poprzez rozwój infrastruktury ruchu turystycznego, wzmacnia funkcje turystyczne miast i regionów ${ }^{38}$.

Tym samym, kapitał transferowany w skali międzynarodowej $\mathrm{w}$ formie bezpośrednich inwestycji zagranicznych, wykazuje tendencję do koncentracji w najbardziej rozwiniętych i zurbanizowanych regionach poszczególnych krajów. Przykładowo, w końcu lat 90. XX wieku, połowa wszystkich przedstawicielstw firm międzynarodowych, zlokalizowanych w Austrii, koncentrowała się w Wiedniu. W Japonii w obszarze metropolitalnym Tokio zlokalizowanych było aż 4/5 przedstawicielstw ${ }^{39}$. Badania realizowane w Polsce wskazały natomiast, iż 55\% KZ koncentruje się w jej ośmiu największych miastach ${ }^{40}$. W przypadku samego regionu (województwa) łódzkiego dostrzega się, że w jego stolicy (Łodzi) oraz sąsiednich gminach, tworzących zwarty obszar metropolitalny, koncentruje się ponad $70 \%$ spółek z udziałem kapitału zagranicznego, zatrudniających 50 i więcej pracowników ${ }^{41}$.

W kontekście powyższych obserwacji, w jednej z polskich aglomeracji cechujących się największym potencjałem ludnościowym i gospodarczym - Łódzkim Obszarze Metropolitalnym - zrealizowano badanie, którego przedmiotem były filie korporacji zlokalizowane $\mathrm{w}$ tym regionie ${ }^{42}$. Celem przedsięwzięcia

${ }^{37}$ 1. Administracyjne (metropolia jako siedziba władz publicznych), 2. decyzyjne (metropolia jako siedziba filii i przedstawicielstw korporacji transnarodowych), 3. komunikacyjne (metropolia węzeł komunikacyjny o znaczeniu międzynarodowym), 4. wiedzy (metropolia jako miejsce sprzyjające powstawaniu innowacji), 5. turystyczne (metropolia jako atrakcyjny produkt turystyczny o znaczeniu międzynarodowym) (ESPON, Study on Urban Functions, Final Report, marzec 2007, s. 9).

${ }^{38}$ M. E. Sokołowicz, Strategie lokalne wobec korporacji transnarodowych jako czynnik integracji lub dezintegracji Łódzkiego Obszaru Metropolitalnego [w:] Lódzka metropolia. Problemy integracji gospodarczej, A. Jewtuchowicz, M. Wójcik (red.), Wydawnictwo Biblioteka, Łódź 2010, s. 109-110.

${ }^{39}$ UNCTAD, World Investment Report, ONZ, Nowy Jork - Genewa 2001, s. 59.

${ }^{40}$ G. Gorzelak, M. Smętkowski, Metropolia i jej region $w$ gospodarce informacyjnej, Wydawnictwo SCHOLAR, Warszawa 2005, s. 67.

${ }^{41}$ M. E. Sokołowicz, Działalność przedsiębiorstw z udziałem kapitału zagranicznego $w$ Łódzkim Obszarze Metropolitalnym na tle międzynarodowych i krajowych przepływów kapitału [w:] Łódzka metropolia. Problemy integracji gospodarczej, A. Jewtuchowicz, M. Wójcik (red.), Wydawnictwo Biblioteka, Łódź 2010, s. 79-80.

${ }^{42} \mathrm{Z}$ uwagi na fakt, że pojęcie „Łódzki Obszar Metropolitalny” nie jest terminem powszechnie znanym lub błędnie interpretowanym wśród osób niezajmujących się zagadnieniami geografii Polski, czy też gospodarki w ujęciu regionalnym, w kwestionariuszu wywiadu pojęcia „ŁOM” 
była $\mathrm{z}$ jednej strony odpowiedź na pytanie o poziom istotności różnych cech kapitału ludzkiego (KL), na tle innych czynników lokalizacji działalności (KL jako czynnik lokalizacji), natomiast z drugiej strony, w jakim stopniu działalność KTN przyczynia się do wzmacniania tego rodzaju zasobu (wpływ korporacji na poziom KL w regionie). Badanie miało charakter ilościowy i polegało na realizacji wywiadów osobistych wśród przedsiębiorstw z udziałem kapitału zagranicznego, funkcjonujących na terenie ŁOM i zatrudniających powyżej 50 pracowników.

Operatem losowania była komercyjna baza firm Hoppenstedt Bonnier Company Database, z której zidentyfikowano grupę 97 przedsiębiorstw, spełniającą założone kryteria według zapisów bazy. W toku dalszej weryfikacji ustalono, iż 12 firm w rzeczywistości nie spełnia kryteriów badania, w związku z czym liczebność operatu wyniosła ostatecznie 85 podmiotów. W trakcie badań udało się dotrzeć do 21 z 85 przedsiębiorstw, a zatem zwrotność badania wyniosła 24,7\%. Wśród 19 podmiotów zrealizowano wywiad osobisty, natomiast w dwóch przypadkach, $\mathrm{z}$ powodu odmowy udziału w wywiadzie osobistym, zrealizowano wywiad telefoniczny. W każdym z wypadków, wywiad oparty był na kwestionariuszu o tej samej, standaryzowanej treści.

Respondentami w badaniu pozostawały osoby zarządzające filiami przedsiębiorstw z udziałem kapitału zagranicznego w randze członków Zarządu (11 przypadków). W pozostałych sytuacjach odpowiedzi udzielały osoby zajmujące inne stanowisko, jednak wskazane jako kompetentne w zakresie zadawanych pytań (np. asystent zarządu, główny księgowy, kierownik ds. handlu, rzecznik prasowy). Choć próba badawcza poddana ostatecznie badaniu nie stanowi próby skonstruowanej w oparciu o dobór probabilistyczny (miał on charakter celowy, oparty na dostępności danych oraz ograniczony niepowszechną w polskich warunkach wolą uczestników do udziału w badaniach), pozwoliła ona na uzyskanie szeregu informacji, w stosunku do których dokonano uogólnienia na całą badaną zborowość.

Pierwszym z istotnych obszarów analiz była identyfikacja czynników, które wiążą się z semantyką pojęcia „kapitał ludzki”, na tle innych czynników lokalizacji, wskazywanych przez badane przedsiębiorstwa. Pozwoliła ona na stwierdzenie, iż ekonomicznie użyteczny zasób wiedzy i umiejętności ludzkich pozostaje ważnym, jednak nie dominującym aspektem wartościującym ŁOM w oczach przedstawicielstw korporacji.

Wśród najczęściej wskazywanych i najwyżej ocenianych czynników lokalizacji znalazły się czynniki związane z minimalizacją kosztów pracy oraz kosztów transportu, jak również aspekty związane $\mathrm{z}$ wielkością i chłonnością rynków zbytu. O ile niskie koszty pracy wskazywane są jako podstawowy walor lokali-

używano zamiennie z pojęciem „Aglomeracja Łódzka”. Zabieg ten odbył się z pełną świadomością różnicy między obydwoma terminami. 
zacyjny regionu, o tyle obecność w nim wykwalifikowanych pracowników znalazło się na liście jego przewag na piątym miejscu. Należy jednak podkreślić, że dokonywane przez respondentów oceny kwalifikacji pracowników były wysokie (mediana ocen 5 oraz 8 jako nota najczęściej wskazywana).

Wykres 1. Czynniki lokalizacji działalności dużych przedsiębiorstw międzynarodowych w Łódzkim Obszarze Metropolitalnym

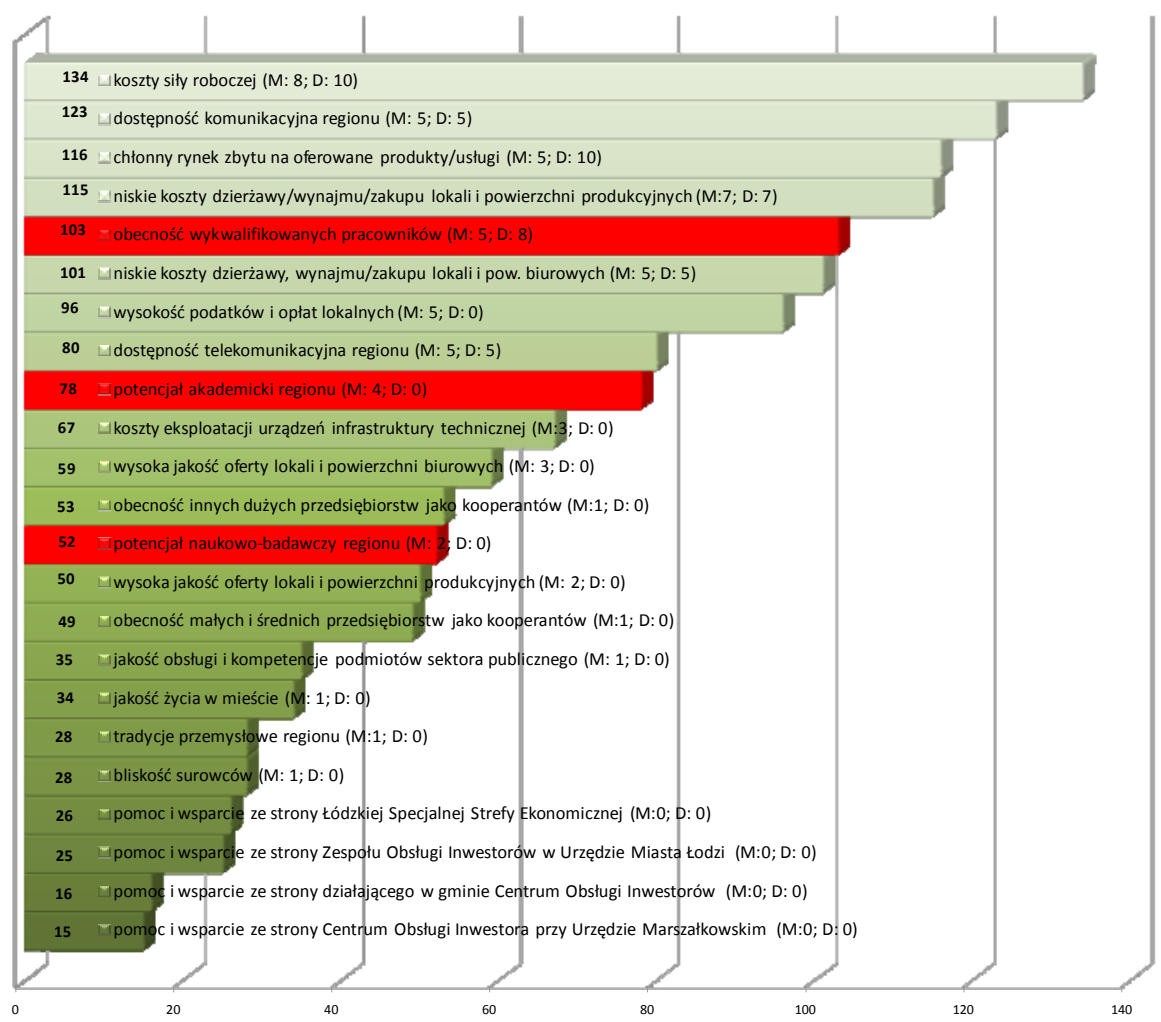

Oznaczenia w nawiasach dotyczą odpowiedzi wskazywanych przez respondentów na skali od 1 do 10, gdzie M - mediana; D - dominanta. Liczby z lewej strony wykresu stanowią sumę ocen dokonanych przez wszystkich respondentów w skali od 1 do 10 .

Źródło: Opracowanie własne, na podstawie wyników badań ankietowych.

Za zjawisko niekorzystne z punktu widzenia wizerunku gospodarczego Łódzkiego Obszaru Metropolitalnego uznać natomiast należy fakt, że potencjał akademicki oraz naukowo-badawczy regionu wskazywane były jako ważne czynniki lokalizacyjne znacznie rzadziej i otrzymywały niższe oceny respondentów. Ponadto, niepokojącym sygnałem pozostają rzadkie wskazania takich aspektów, jak obecność 
innych przedsiębiorstw jako kooperantów, kompetencja pracowników sektora publicznego oraz pomoc i wsparcie ze strony różnorodnych podmiotów polityki proinwestycyjnej (por. wykres 2). Oznacza to bowiem pośrednio niską ewaluację kapitału drzemiącego w otoczeniu lokalnym badanych przedsiębiorstw. Innymi słowy, poziom oszacowania kapitału ludzkiego w różnorodnych jego formach (zarówno przez pryzmat kwalifikacji własnych pracowników, jak i osób zatrudnionych poza strukturami firm, lecz wchodzących z nimi w interakcje o charakterze biznesowym i pozabiznesowym), na tle bardziej ,pierwotnych” czynników lokalizacji (koszty pracy, koszty transportu, dostępność rynków, etc.), oceniony został przez badane filie korporacji z dużą dozą powściagliwości.

Wykres 2. Ocena oferty instytucji wiedzy w oczach dużych przedsiębiorstw międzynarodowych w Łódzkim Obszarze Metropolitalnym

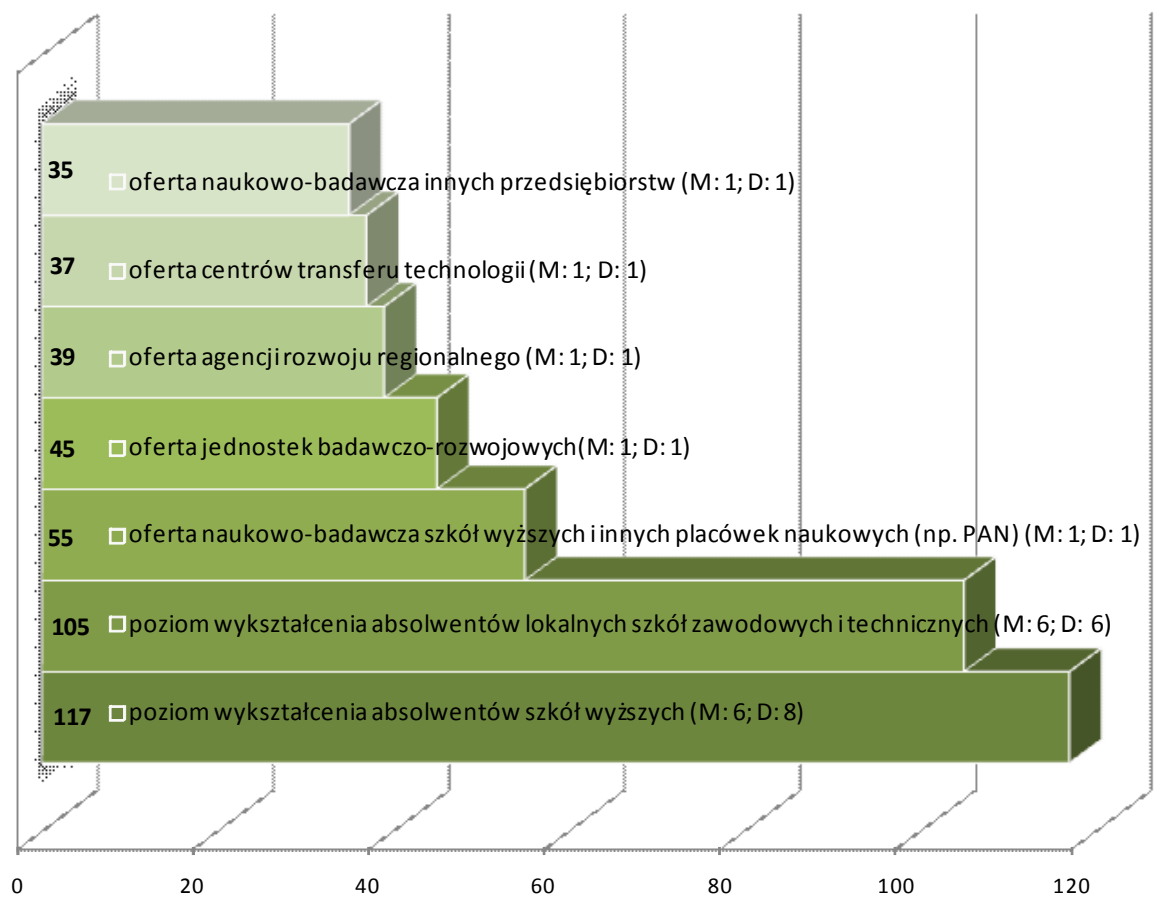

Oznaczenia w nawiasach dotyczą odpowiedzi wskazywanych przez respondentów na skali od 1 do 10, gdzie M - mediana; D - dominanta. Liczby z lewej strony wykresu stanowią sumę ocen dokonanych przez wszystkich respondentów w skali od 1 do 10.

Źródło: Opracowanie własne, na podstawie wyników badań ankietowych. 
Kolejnym istotnym źródłem informacji o poziomie ,zastanego” w regionie kapitału ludzkiego mogą być oceny efektów funkcjonowania instytucji wiedzy, z punktu widzenia ich znaczenia dla inwestorów. W tym ujęciu, duże przedsiębiorstwa $\mathrm{z}$ udziałem kapitału zagranicznego najwyżej oceniają poziom wykształcenia absolwentów szkół wyższych. Warto zauważyć, że połowa badanych przedsiębiorstw oceniała ten czynnik na poziomie nie mniejszym niż 6 na dziesięciostopniowej skali, natomiast dominującym poziomem oceny było 8 . Na nieco niższym, jednak podobnym poziomie oceniano także poziom wykształcenia absolwentów lokalnych szkół zawodowych i technicznych.

Za zdecydowanie mniej atrakcyjne dla inwestorów okazały się oferty innych podmiotów wiedzy $\mathrm{w}$ regionie, i to zarówno placówek naukowych i jednostek badawczo-rozwojowych, jak i przedsiębiorstw. Pozwala to zakładać, iż badane przedsiębiorstwa nie upatrują atrakcyjności regionu zarówno w samej ofercie, jak i w zasobach ludzkich tych podmiotów. Podobnie niekorzystna ocena dotyczyła agencji rozwoju regionalnego oraz centrów transferu technologii. Zarówno niska ocena oferty $\mathrm{B}+\mathrm{R}$ przedsiębiorstw działających $\mathrm{w}$ regionie, jak i centrów transferu technologii także wskazuje na pewną niekorzystną sytuację. Wiąże się ona $\mathrm{z}$ faktem, że najmniejszą atrakcyjnością w oczach inwestorów cechują się te podmioty zajmujące się komercjalizacją wiedzy i innowacji, które w gospodarce rynkowej należy uznać za najbardziej efektywne formy waloryzacji kapitału ludzkiego.

W przypadku oceny znaczenia współpracy przedsiębiorstw z instytucjami wiedzy, prezentuje się ona w sposób podobny do samego postrzegania oferty tych podmiotów. Innymi słowy, o ile w przypadku przyjmowania studentów na praktyki i staże, badane przedsiębiorstwa deklarowały tę formę współpracy oraz relatywnie wysoko ją oceniały, o tyle w odniesieniu do bardziej ,zaawansowanych" form kooperacji, rysujący się obraz nie napawa optymizmem.

Szczególnie negatywnie należy interpretować fakt, że w każdym z analizowanych obszarów współpracy, dominowała ocena 0 (wskazująca na brak zainteresowania współpracą z instytucjami wiedzy ze strony filii korporacji transnarodowych). Sytuacja ta dotyczy także najprostszej, jak by się mogło wydawać formuły współpracy, tj. przyjmowania studentów na staże i praktyki, która otrzymała od respondentów najwyższą ocenę.

Niewielka część badanych przedsiębiorstw wskazywała i podejmowała się oceny (niestety niskiej) pozostałych obszarów współpracy z instytucjami wiedzy. Wśród nich można wskazać ,zakup” wiedzy o charakterze przede wszystkim nietechnologicznym (konsultacje, ekspertyzy, doradztwo, szkolenia) oraz pierwsze w regionie próby otwierania kierunków studiów o profilu odpowiadającym potrzebom przedsiębiorstw. 
Wykres 3. Ocena znaczenia poszczególnych obszarów współpracy z instytucjami wiedzy $w$ Łódzkim Obszarze Metropolitalnym dla dużych przedsiębiorstw międzynarodowych

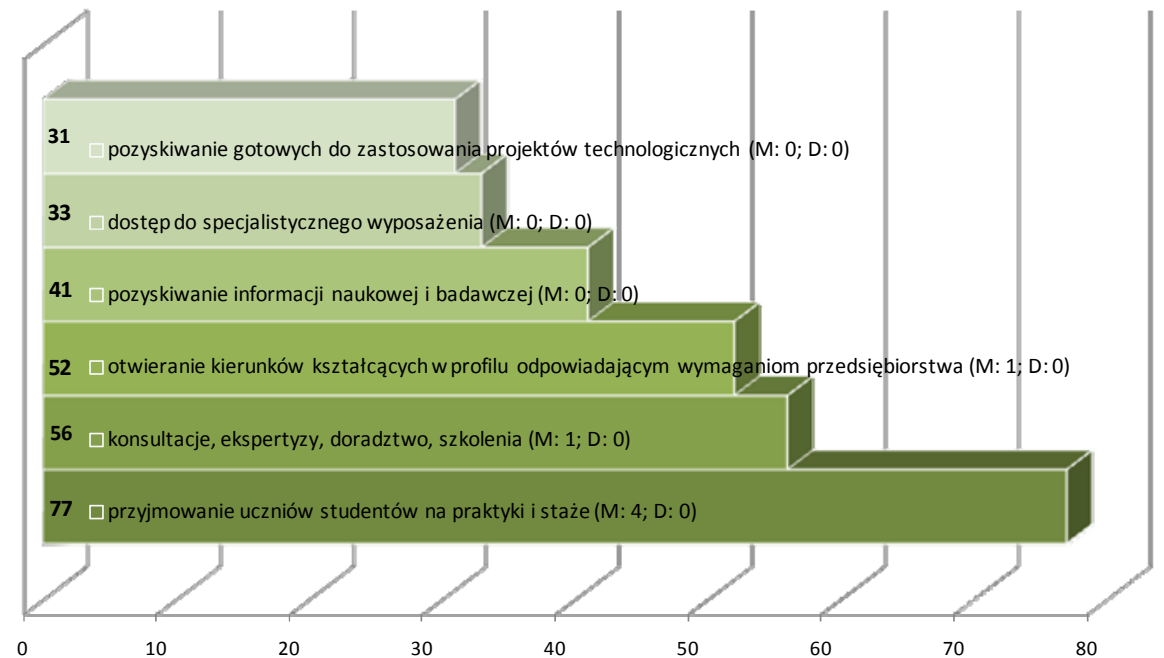

Oznaczenia w nawiasach dotyczą odpowiedzi wskazywanych przez respondentów na skali od 1 do 10, gdzie M - mediana; D - dominanta. Liczby z lewej strony wykresu stanowią sumę ocen dokonanych przez wszystkich respondentów w skali od 1 do 10.

Źródło: Opracowanie własne, na podstawie wyników badań ankietowych.

Zdecydowanie najniższe oceny otrzymywały takie obszary, jak pozyskiwanie wyników badań realizowanych przez działające w Aglomeracji Łódzkiej (przede wszystkim w samej Łodzi) instytucje wiedzy, czy też użyczanie specjalistycznego wyposażenia oraz pozyskiwanie gotowych rozwiązań technologicznych. Innymi słowy, zlokalizowane $w$ regionie przedstawicielstwa dużych przedsiębiorstw działających $\mathrm{w}$ skali międzynarodowej, zdecydowanie nisko oceniają zarówno jego ofertę technologiczną, jak i poziom jej dostosowania do ich potrzeb.

Powyższa sytuacja skłania do identyfikacji barier współpracy filii KTN z regionalnymi instytucjami wiedzy, wśród których - zdaniem badanych inwestorów - dominują aspekty o charakterze informacyjnym oraz te, związane z dostosowaniem podaży oferty do potrzeb sektora przedsiębiorstw. 
Tabela 3. Bariery współpracy z instytucjami wiedzy w oczach dużych przedsiębiorstw międzynarodowych działających w Łódzkim Obszarze Metropolitalnym

\begin{tabular}{|l|c|}
\hline \multicolumn{1}{|c|}{ Bariery } & $\begin{array}{c}\text { Suma ocen dokonanych } \\
\text { przez respondentów } \\
\text { w skali od 1 do 10 }\end{array}$ \\
\hline Brak informacji o funkcjonowaniu instytucji wiedzy & 82 \\
\hline $\begin{array}{l}\text { Ograniczone możliwości adaptacji oferowanych rozwiązań } \\
\text { w ramach działalności firmy }\end{array}$ & 82 \\
\hline Zła jakość oferty instytucji wiedzy & 76 \\
\hline Brak zaufania do instytucji wiedzy & 45 \\
\hline Zbyt mała liczba/brak instytucji wiedzy w mieście/regionie & 43 \\
\hline Niechęć instytucji wiedzy do podejmowania współpracy & 43 \\
\hline
\end{tabular}

Źródło: Opracowanie własne, na podstawie wyników badań ankietowych.

Wskazywanie braku informacji oraz możliwości transferu wiedzy i technologii jako najważniejszych barier współpracy, wbrew pozorom stwarza możliwości dla poprawy istniejącej sytuacji, w wyniku stosowana przemyślanej polityki innowacyjnej. Należy bowiem dostrzec, że takie bariery, jak brak zaufania do instytucji wiedzy, niechęć z ich strony do podejmowania współpracy lub ich zbyt mała ilość, nie są w oczach respondentów dominującymi ograniczeniami w budowaniu powiązań kooperacyjnych. Tym samym, prowadzenie skutecznej polityki informacyjnej jako narzędzi promocji lokalnej i regionalnej oferty instytucji wiedzy (zadanie łatwiejsze) oraz działania na rzecz zbudowania skutecznego systemu transferu technologii (zadanie niewatpliwie trudniejsze i bardziej złożone, lecz możliwe), jawią się w świetle powyższych badań jako podstawowe kierunki polityki wzmacniania wiedzy w regionie w najbliższych latach.

$\mathrm{Z}$ punktu widzenia celów rozwoju regionów, korporacje transnarodowe nie tylko powinny czerpać, ale i angażować się we wzmacnianie poziomu i jakości lokalnego kapitału ludzkiego. W odniesieniu do aglomeracji łódzkiej i Łódzkiego Obszaru Metropolitalnego, zarówno kierunki, jak i poziom tego zaangażowania pozostaje zróżnicowany. Dostrzega się przy tym, że dominują te formy inwestycji w kapitał ludzki, które dotyczą samych przedsiębiorstw, natomiast wpływ badanych przedsiębiorstw na rozwój lokalnych zasobów wiedzy odbywający się poprzez współpracę z lokalnym otoczeniem, pozostaje ograniczony. 
Wykres 4. Kierunki i poziom zaangażowania badanych przedsiębiorstw w transfer innowacyjnych rozwiązań oraz poprawę jakości kapitału ludzkiego

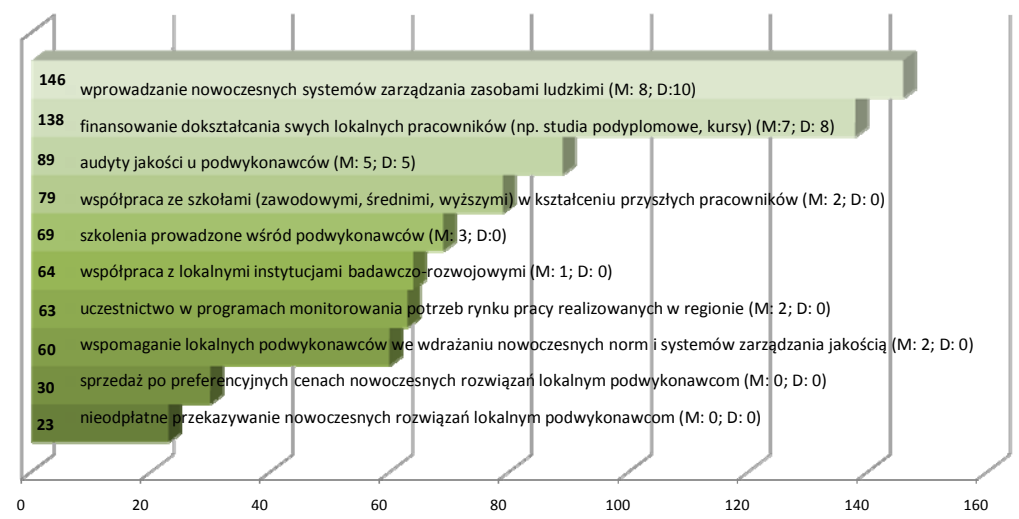

Oznaczenia w nawiasach dotyczą odpowiedzi wskazywanych przez respondentów na skali od 1 do 10, gdzie M - mediana; D - dominanta. Liczby z lewej strony wykresu stanowią sumę ocen dokonanych przez wszystkich respondentów w skali od 1 do 10 .

Źródło: Opracowanie własne, na podstawie wyników badań ankietowych.

W tym kontekście, badane filie KTN jako najczęściej stosowane i najważniejsze z ich punktu widzenia formy wzmacniania kwalifikacji kapitału ludzkiego, wskazywały wprowadzanie wewnętrznych systemów zarządzania zasobami ludzkimi oraz finansowanie dokształcania własnych pracowników. Rzadziej wskazywano natomiast audyty jakości u podwykonawców oraz współpracę z lokalnymi szkołami zawodowymi, średnimi i wyższymi. Szczególnie w odniesieniu do powiązań z instytucjami edukacyjnymi, zwraca uwagę dość niska ocena ich oferty, co znalazło potwierdzenie w jej niskich średnich notach.

Zdecydowanie najrzadziej wskazywano oraz najniżej oceniano te elementy lokalnego „systemu wiedzy”, które formowane są i wzmacniane poprzez kooperację z otoczeniem. Innymi słowy, skłonność filii korporacyjnych do współpracy z lokalnymi przedsiębiorstwami, szkołami, instytucjami $\mathrm{B}+\mathrm{R}$, etc., pozostaje wciąż niezwykle niska. Co istotne, o ile nie dziwi brak skłonności do nieodpłatnego przekazywania własnego know-how lokalnym kooperantom, o tyle brak chęci do organizowania z nimi wspólnych szkoleń, bądź uczestnictwa w programach monitorowania regionalnego rynku pracy, uznać należy za przejaw niskiej skłonności badanych przedsiębiorstw do terytorializacji.

Ostatnim elementem analizy mającej na celu identyfikację poziomu zaangażowania KTN w rozwój kapitału ludzkiego, była struktura pochodzenia kadry, 
w podziale na pracowników poszczególnych szczebli struktur organizacyjnych przedsiębiorstw. Podstawową konkluzją, jaka z niej płynie pozostaje spostrzeżenie, że udział pracowników pochodzących spoza Polski wzrastał wraz z poziomem wymaganych kwalifikacji.

Tabela 4. Struktura pochodzenia kadry w badanych przedsiębiorstwach - poziom umiędzynarodowienia kapitału ludzkiego

\begin{tabular}{|l|c|c|}
\hline \multicolumn{1}{|c|}{ Pracownicy } & Pracownicy lokalni w \% & Pracownicy zagraniczni w \% \\
\hline Kadra zarządzająca & 85,60 & 14,40 \\
\hline Kadra administracyjna & 88,33 & 11,67 \\
\hline Kadra inżynierska & 77,14 & 22,86 \\
\hline Pracownicy techniczni & 86,19 & 13,81 \\
\hline Pracownicy produkcji & 99,99 & 0,010 \\
\hline
\end{tabular}

Źródło: Opracowanie własne, na podstawie wyników badań ankietowych.

Tym samym, o ile w przypadku pracowników produkcyjnych ${ }^{43}$ dostrzega się zatrudnianie niemal wyłącznie pracowników lokalnych, o tyle w przypadku kadry zarządzającej niższego i wyższego szczebla oraz niższej kadry technicznej, udział pracowników z zagranicy wzrasta do ponad $10 \%$. Zwraca też uwagę, iż najwyższy udział pracowników zagranicznych zanotowano w odniesieniu do kadry inżynierskiej $(22,9 \%)$. Obserwacje te warto porównać z wynikami podobnych badań realizowanych przez autora w Aglomeracji Łódzkiej w okresie od lipca do grudnia 2005 roku. Z porównania tego wynika, że na przestrzeni 5 lat dostrzegalnie wzrósł udział kadry pochodzenia zagranicznego, która $\mathrm{w}$ roku 2005 przekraczała wprawdzie $21 \% \mathrm{w}$ przypadku menedżerów wyższego szczebla, jednak w odniesieniu do pozostałych grup (kadra zarządzająca niższego szczebla, kadra techniczna oraz pracownicy produkcyjni), nie przekraczała $3 \%{ }^{44}$.

Można zaryzykować stwierdzenie, że istotny spadek udziału kadry zarządzającej wyższego szczebla $\mathrm{w}$ strukturze zatrudnienia jest prawdopodobnie skutkiem tego, że podmioty z udziałem kapitału zagranicznego, po okresie uruchamiania działalności gospodarczej w regionie nabyły zaufania do kadry lokalnej. Należy jednakże pamiętać, że z perspektywy korporacji, przymiotnik „lokalna” nie ogranicza się do kadry $\mathrm{z}$ jednego regionu, ale $\mathrm{z}$ całego kraju. Znajduje to

${ }^{43}$ Wśród badanych przedsiębiorstw znalazły się także podmioty spoza sektora produkcji (6 z 21). W ich przypadku, za pracowników ,produkcyjnych” uznawano osoby zatrudnione na stanowiskach związanych z bezpośrednią obsługą klientów.

${ }^{44}$ M. E. Sokołowicz, Region wobec procesów globalizacji-terytorializacja przedsiębiorstw międzynarodowych (na przykładzie regionu tódzkiego), Prace Doktorskie z Zakresu Ekonomii i Zarządzania, Wydawnictwo Uniwersytetu Łódzkiego, Łódź 2008, s. 107-109. 
także potwierdzenie w badaniach A. Kłysik-Uryszek, prowadzonych w roku 2008 na terenie województwa łódzkiego. Zgodnie z ich wynikami, inwestorzy zagraniczni nie zgłaszają $\mathrm{w}$ regionie łódzkim zapotrzebowania na menedżerów najwyższych szczebli $\mathrm{z}$ doświadczeniem na rynku lokalnym. W większości przypadków menedżerowie pochodzą z innych lokalizacji spółki w Polsce, lub na średnim szczeblu - są szkoleni przez spółki we własnym zakresie ${ }^{45}$. Z drugiej strony, $50 \%$ badanych podmiotów szkoli swych pracowników w swych zagranicznych oddziałach ${ }^{46}$.

Wzrost udziału kadry zagranicznej, zwłaszcza w przypadku inżynierskiej oraz technicznej, na obecnym etapie rozwoju regionu, należy uznać za zjawisko pozytywne. Sytuacja ta stwarza szerokie możliwości wymiany doświadczeń między kadrą lokalną oraz pochodzącą spoza regionu i w opinii autora stanowi najbardziej pozytywny wyraz wpływu działalności filii korporacji, na wzmacnianie lokalnego kapitału ludzkiego. Pozostaje mieć jedynie nadzieję, że kolejne lata nie przyniosą ze sobą delokalizacji KTN z regionu, ale istotne rozszerzenie obszarów wpływu tego typu podmiotów gospodarczych, na wzmacnianie lokalnych i regionalnych zasobów ludzkich. Obecne badania nie pozwalają bowiem na wysnucie takich wniosków.

\section{Podsumowanie}

Rozwijane od lat badania nad tzw. kapitałem ludzkim i jego rolą w procesach wzrostu i rozwoju gospodarczego nieustannie ewoluują. Jednym z coraz częściej uwzględnianych przez ekonomistów poziomów analizy tego zagadnienia jest poziom regionalny. Dlatego też coraz więcej badań dotyczy wzmacniania kapitału ludzkiego w regionie, postrzeganego jako jeden z kluczowych czynników rozwoju w tzw. gospodarce opartej na wiedzy.

Należy przy tym podkreślić, że współczesne gospodarki regionalne pozostają otwarte na otoczenie międzynarodowe, a jednym z przejawów tej otwartości jest fakt lokalizowania się w nich filii i przedstawicielstw korporacji transnarodowych. Relacje pomiędzy tymi podmiotami gospodarczymi a regionami należy przy tym rozpatrywać dwustronnie, bowiem realizowane przez KTN, bezpośrednie inwestycje zagraniczne traktują zakorzeniony w regionie kapitał ludzki jako czynnik lokalizacyjny, ale w sprzyjających okolicznościach KTN mogą także przyczyniać się do wzmacniania tego rodzaju kapitału.

${ }^{45}$ A. Kłysik-Uryszek, Bezpośrednie inwestycje zagraniczne $w$ gospodarce regionu. Teoria i praktyka, Wydawnictwo CeDeWu, Warszawa 2010, s. 183.

${ }^{46}$ A. Kłysik-Uryszek, Bezpośrednie inwestycje zagraniczne $w$ gospodarce regionu. Teoria i praktyka, Wydawnictwo CeDeWu, Warszawa 2010, s. 184. 
Powyższe założenia dotyczące relacji między działalnością korporacji a rozwojem kapitału ludzkiego w regionie, poddane zostały weryfikacji empirycznej w odniesieniu do Łódzkiego Obszaru Metropolitalnego. Wyniki badania prowadzą do dwóch podstawowych wniosków, zgodnie z którymi:

1. W badanym systemie terytorialnym kapitał ludzki pozostaje ważnym, choć nie najistotniejszym czynnikiem lokalizacji filii KTN;

2. Drugie $z$ analizowanych zjawisk, polegające na pozytywnym oddziaływaniu KTN na kapitał ludzki, na obecnym etapie rozwoju aglomeracji nie zachodzi w wyraźnie dostrzegalny sposób.

Należy podkreślić, że biorące udział w badaniu filie korporacji funkcjonujących $\mathrm{w}$ obszarze metropolitalnym, jako najważniejsze czynniki lokalizacyjne eksponują w pierwszej kolejności koszty, a dopiero potem wysoką jakość siły roboczej. Ponadto, w świetle badania dobrze oceniane są kwalifikacje absolwentów lokalnych szkół średnich i wyższych, natomiast potencjał lokalnych instytucji $\mathrm{B}+\mathrm{R}$ oraz umiejętności ich pracowników oceniane są relatywnie słabiej. Obserwacje te prowadzą do wniosku, że „transfer wiedzy” z regionu do KTN przyjmuje najprostsze formy (,,przechwytywanie” zasobów poprzez zatrudnianie pracowników bezpośrednio w przedsiębiorstwach), natomiast rzadko dokonuje się w formach zaawansowanych, opartych na logice sieci i na współpracy ich filii z lokalnym otoczeniem oraz budowaniem powiązań pionowych i poziomych.

Jednakże, porównanie struktury zatrudnienia pracowników korporacji w Łódzkim Obszarze Metropolitalnym ze strukturą zaobserwowaną w roku 2005 pozwala dostrzec, że region staje się pod tym względem regionem coraz bardziej umiędzynarodowionym. Tym samym należy stwierdzić, że zaobserwowana sytuacja jest w większym stopniu pochodną obecnego etapu rozwoju gospodarczego, niż konsekwencją błędnej strategii regionu w obszarze przyciagania bezpośrednich inwestycji zagranicznych.

$\mathrm{Z}$ tego punktu widzenia, podstawowym wyzwaniem dla polityki dotyczącej inwestycji zagranicznych $\mathrm{w}$ regionie wydaje się być nie tyle jej całkowita reorientacja, ile silniejsze eksponowanie znaczenia innych poza tradycyjnymi, czynników rozwoju gospodarczego (koszty pracy, dostępność komunikacyjna), tj. wiedzy, kapitału ludzkiego i regionalnie budowanego kapitału społecznego. W obszarze rekomendacji dla tego rodzaju polityki należy w pierwszej kolejności wspomnieć o konieczności większej promocji istniejącego w regionie potencjału wiedzy, a w dalszej stymulować jego dalszy, przyspieszony rozwój. Drugi z wymienionych warunków, wymaga jednakże odwołania się do konieczności wypracowania umiejętności identyfikowania kluczowych, z punktu widzenia potencjału rozwojowego, sektorów gospodarki (ang. emerging industries), które mogłyby być obszarem silniejszego zainteresowania ze strony podmiotów, od- 
powiedzialnych za kreowanie i realizację polityki proinwestycyjnej, kierowanej do dużych międzynarodowych przedsiębiorstw.

Warto podkreślić, że skuteczność proponowanych działań warunkowana jest także świadomością faktu, że polityka wobec bezpośrednich inwestycji zagranicznych nie może być oparta na podejściu „sektorowym”, ale „terytorialnym”, odwołującym się do zdolności eksponowania specyficznych przewag konkurencyjnych Łódzkiego Obszaru Metropolitalnego, które w znacznym stopniu drzemią w lokalnie zakorzenionym (a być może jeszcze nie odkrytym), kapitale ludzkim. Podejście terytorialne oznaczać powinno ponadto zdolność do łączenia w jednym miejscu celów i działań realizowanych w obszarze innych polityk, jak np. polityka przemysłowa, polityka promocji, wspierania klastrów i polityka innowacyjna (w świadomości decydentów wciąż mało doceniana) ${ }^{47}$, czy też w zasadzie nieobecna $\mathrm{w}$ tej chwili $\mathrm{w}$ regionie łódzkim, polityka rozwoju kapitału ludzkiego. Co więcej, zorientowana terytorialnie polityka stymulowania konkurencyjności regionalnej powinna być oparta na trafnie dobranych narzędziach diagnostycznych, gdzie foresight czy polityka klastrowa nie powinny pozostawać hasłami, ale trwałą idea, silnie zakorzenioną w świadomości podmiotów polityki regionalnej, uwzględniającą przy tym kierunki zachowań strategicznych dużych międzynarodowych przedsiębiorstw.

\section{Bibliografia}

Amin A., Cohendet P., Learning and Adaptation in Decentralised Business Networks, Environment and Planning D: Society and Space, 17, 1999.

Becker G., Investment in Human Capital: A Theoretical Analysis, Journal of Political Economy, Vol. 70, 1962.

Coase R., The nature of the firm, Economica 1937, 4 (16).

Dicken P., Global Shift. Internationalization of Economic Activity, The Guilford Press, New York-London 1992.

Domański, S. R., Kapitał ludzki i wzrost gospodarczy, Wydawnictwo Naukowe PWN, Warszawa 1993.

Donakowski A., Wplyw bezpośrednich inwestycji zagranicznych na transfer technologii do polskiej gospodarki [w:] Bezpośrednie inwestycje zagraniczne w Polsce, Karaszewski W. (red.), Wydawnictwo Uniwersytetu Mikołaja Kopernika, Toruń 2003.

Dunning J. H., Explaining International Production, Unwin Hyman, Londyn 1988.

Edquist Ch. (red.), Systems of Innovations: Technologies, organizations, and institutions, Printer Publishers/Cassel Academic, London 1997.

ESPON, Study on Urban Functions, Final Report, marzec 2007.

${ }^{47}$ Por. A. Nowakowska, Regionalny wymiar procesów innowacji, Wydawnictwo Uniwersytetu Łódzkiego, Łódź 2011, s. 176-178. 
Gorzelak G., Smętkowski M., Metropolia i jej region w gospodarce informacyjnej, Wydawnictwo SCHOLAR, Warszawa 2005.

Grodzicki J., Rola kapitału ludzkiego w rozwoju gospodarki globalnej, Wydawnictwo Uniwersytetu Gdańskiego, Gdańsk 2003.

Grzegorczyk W., Strategie wejścia polskich przedsiębiorstw na rynki zagraniczne, Wydawnictwo Stardruk, Warszawa 2006.

Hardt Ł., Ekonomia kosztów transakcyjnych - geneza i kierunki rozwoju, Wydawnictwa Uniwersytetu Warszawskiego, Warszawa 2009.

Herbst M., Kapitat ludzki, dochód $i$ wzrost gospodarczy w badaniach empirycznych [w:] Kapitat ludzki i kapitał społeczny a rozwój regionalny, Herbst M. (red.), Wydawnictwo SCHOLAR, Warszawa 2007.

Kłysik-Uryszek A., Bezpośrednie inwestycje zagraniczne w gospodarce regionu. Teoria i praktyka, Wydawnictwo CeDeWu, Warszawa 2010.

Kukliński A. (red.), The Knowledge-Based Economy. The European Challenges of the $21^{\text {st }}$ Century, KBN, Warszawa 2000.

Lucas R. E. Jr, Why Doesn't Capital Flow from Rich to Poor Countries, American Economic Review, no. 89, 1990.

Marshall A., Principles of Economics, Macmillan, London 1920.

Mincer J., Investment in Human Capital and Personal Income Distribution, Journal of Political Economy, Vol. 66, 1958.

Mincer J., Schooling Experience and Learning, Columbia University Press, New-York London 1974.

Nohria N., Ghoshal S., The Differentiated Network: Organizing Multinational Corporations for Value Creation, Jossey-Bass Publishers, San Francisco 1997.

Noorbakhsh F., Paloni A., Youssef A., Human Capital and FDI Inflows to Developing Countries: New Empirical Evidence, World Development, Vol. 29, no. 9, 2001.

Nowakowska A., Przygodzki Z., Sokołowicz M. E., Region w gospodarce opartej na wiedzy. Kapital ludzki - innowacje - korporacje transnarodowe, Wydawnictwo Difin, Warszawa 2011.

Nowakowska A., Bąkowski A., Klaster [w:] Innowacje i transfer technologii. Stownik pojęć, Matusiak K. B. (red.), Polska Agencja Rozwoju Przedsiębiorczości, Warszawa 2008.

Nowakowska A., Regionalny wymiar procesów innowacji, Wydawnictwo Uniwersytetu Łódzkiego, Łódź 2011.

Oleksiuk A., Inwestowanie w kapitał ludzki w Polsce, Wydawnictwo ECONOMICUS, Szczecin 2009.

Pakulska T., Poniatowska-Jaksch M., Globalne pozyskiwanie zasobów-zarys problemu, Gospodarka Narodowa, 1-2, 2008.

Phelps N. A., Cluster or Capture? Manufacturing Foreign Direct Investment, External Economies and Agglomeration, Regional Studies, Vol. 48, issue 4, 2008.

Pietrzyk I., Polityka regionalna Unii Europejskiej i regiony w państwach członkowskich, Wydawnictwo Naukowe PWN, Warszawa 2001.

Pilarska C., Bezpośrednie inwestycje zagraniczne a transfer technologii [w:] Bezpośrednie inwestycje zagraniczne w Polsce, Karaszewski W. (red.), Wydawnictwo Uniwersytetu Mikołaja Kopernika, Torun 2003.

Porter M. E., On Competition, Harvard University Press, Boston 2008. 
40 Wpływ korporacji transnarodowych na wzmacnianie kapitału ludzkiego...

Schultz T. W., Investment in Human Capital, The American Economic Review, Vol. 51 (1), 1961.

Sokołowicz M. E., Działalność przedsiębiorstw z udziałem kapitału zagranicznego $w$ Lódzkim Obszarze Metropolitalnym na tle międzynarodowych i krajowych przepływów kapitału [w:] Lódzka metropolia. Problemy integracji gospodarczej, Jewtuchowicz A., Wójcik M. (red.), Wydawnictwo Biblioteka, Łódź 2010.

Sokołowicz M. E., Region wobec procesów globalizacji - terytorializacja przedsiębiorstw międzynarodowych (na przykładzie regionu łódzkiego), Prace Doktorskie z Zakresu Ekonomii i Zarządzania, Wydawnictwo Uniwersytetu Łódzkiego, Łódź 2008.

Sokołowicz M. E., Strategie lokalne wobec korporacji transnarodowych jako czynnik integracji lub dezintegracji Łódzkiego Obszaru Metropolitalnego [w:] Lódzka metropolia. Problemy integracji gospodarczej, Jewtuchowicz A., Wójcik M. (red.), Wydawnictwo Biblioteka, Łódź 2010.

Taymaz E., Kiliçaslan Y., Determinants of Subcontracting and Regional Development: An Empirical Study on Turkish Textile and Engineering Industries, Regional Studies, Vol. 39.5.

UNCTAD, The Competitiveness Challenge: Transnational Corporations and Industrial Restructuring in Developing Countries, Geneva 2000.

UNCTAD, World Investment Report, ONZ, Nowy Jork - Genewa 1994.

UNCTAD, World Investment Report, ONZ, Nowy Jork - Genewa 2001.

Walukiewicz S., Kapitał ludzki. Skrypt akademicki, Instytut Badań Systemowych Polskiej Akademii Nauk, Warszawa 2010.

Williamson O., Market and hierarchies. Analysis and Antitrust Implications, Free Press, Nowy Jork 1975.

World Bank, Knowledge and Development. World Development Report, Oxford University Press 1998.

Zorska A., Korporacje transnarodowe: przemiany, oddziaływania, wyzwania, Polskie Wydawnictwa Ekonomiczne, Warszawa 2007. 